\title{
School Culture Development In SMK Negeri 9 Padang
}

\author{
Ranti Meizatri ${ }^{\mathrm{a}}$, Rusdinal ${ }^{\mathrm{b}}$, Rifma $^{\mathrm{c}}$ \\ Department of Educational Management \\ Universitas Negeri Padang \\ Padang, Indonesia
}

Corresponding e-mail: ${ }^{a}$ Ranti16.meizatri@gmail.com, ${ }^{b}$ rusdinalhar@yahoo.com, ${ }^{c}$ Rifmar34@gmail.com

\begin{abstract}
The development of students' work character through the development of Vocational High School culture is an urgent thing to be done in order to prepare graduates who poss the required job qualification. The aim of the research was to obtain data and information about school culture development in vocational high school. The research employed qualitative research. This research was done in Sekolah Menengah Kejuruan (SMK) Negeri 9 Padang which is one of the favorite vocational high school with all accredited skills program A. Subjects in this research were principal, head of study program, teachers, employees, and pupils. Data in this research was collected by using observation, interview, and documentation study. Data were analyzed through three stages: data reduction, data presentation, and conclusion. The results show that school culture development is conducted through quality policy in training and educational programs, establishing regulations, and values socialization. Unfortunately, it is recommended to the principal to develop the School culture by adjusting the spectrum characteristics of each Vocational School.
\end{abstract}

Keyword: School Culture, Development, Vocational High School

\section{INTRODUCTION}

Vocational High School (SMK) plays an important role in preparing generation to compete in various sectors of the economy. Vocational education or vocation that is oriented in the preparation of skilled manpower is expected to become the driving force of local and even national economic strengthening. In Law $20 / 2003$ on the National Education System Article 15, it is stated that the existence of SMK is designed to prepare graduates working in certain fields. This shows that vocational secondary education is aimed to produce graduates who are ready to work, either working independently or working in a particular industry. SMK is required to produce graduates as expected by the school, community, and Business World / Industrial World.

SMK as a vocational education institution is expected to create a workforce that controls the work competence in accordance with the field, the ability to adapt, and high competitiveness. But in general the problem faced that is not all SMK are able to answer the problem of labor requirements that meet the qualifications required by the world of work. Quantity of vocational graduates who are not absorbed in the business world and the industrial world is quite high. Data from the Central Bureau of Statistics (BPS) in the last 5 years (2010 up to 2015) the level of high school graduates $(90.74 \%)$ is higher than the vocational graduates $(89.19 \%)$. (BPS, Sakernas 2000, 2005, 2010.2015 The average of February and August or November). Based on the educational status, vocational graduates are the most idle. The number reached 813,776 people or 11.24 percent of the total open unemployment rate (Republika.co.id: 2016). This problem is indicated due to the low competence of graduates, incompatibility of competencies trained in SMK with the needs of DU / DI and the lack of mental readiness to work after graduated from vocational school.

The existence of the current SMK is still considered less in the preparation of graduates as a workforce. There is a difference of interest between the world of education with industrial world because the world wants a graduate school that has a high value in a short time while the industry wants graduates with technical competence and a good attitude (Callan: 2003; Clarke, 2007). SMK graduates are considered less equipped with two basic competencies required by the industry that is the ability of hard skills and soft skills. Competences of hard skills are skills that are used to work in the fields of expertise, and competence of attitude, cooperation, motivation belonging to the soft skills. O'Brien (1997) describes that soft skills include communication skills, organizational skills, leadership skills, logic skills, effort skills, group skills and ethics. The results of the research interview (March 4, 2017) with one of the SMK teachers showed many cases of students who returned to school before the apprenticeship is over. This happens because the lack of readiness of learners to adapt to the dynamics of work culture in the industry.

The new job skills needed by the workforce have also changed; new workers with more logical thinking skills, while SMK still supplies graduates with unchanged skills. The assumption that vocational education only prepares a workforce with 
certain skills, making learners tends to exclude the academic aspects in the process of knowledge development. On the other hand, the lack of interest in reading is also a cause of learners' weak knowledge toward science and new innovations that develop especially in the field of expertise he took. On the other hand SMK has not been able to create a replica of the industry in school. Learners are accustomed to casual hours of study and work, while in the industry they have to work hard with an hourly average of 40 hours per week. Teachers and learners are lack of understanding of Market, Insight Quality, Excellence, and Competition. In practice, students are left to work in the wrong way and mistakes are accepted and forgiven as a reasonableness. The quality of the work is left as it is without quality standards. Therefore SMK graduates have less concern and relevance to quality, because schools do not teach the risks of losses for failures, whereas industry failure is a loss that must be borne by workers.

December 19, 2016 President of the Republic of Indonesia issued Presidential Instruction No. 9 of 2016 on the revitalization of SMK. This Presidential Decree is issued in the framework of improving the quality and competitiveness of Indonesian human resources which is the direction of vocational education development in the future. To support the implementation of this Impres, the institutional SMK must make internal improvements. Starting from the preparation of school programs, curriculum improvements, and empowerment of facilities and infrastructure to the development of school culture. This is supported by Permend no. 19 of 2007 on education management standards that include culture and environment as one of the school management objectives. The development of school culture is also used as one of the principal's work program for the implementation of the 2013 curriculum (LP2TK: 2014).

Luneburg \& Ornstain (2000: 60) mention "The culture of an organizational is all the beliefs, feelings, behaviors, and symbols that are characteristic of an organization. More specifically, organization culture is defined as share philosophies, ideologies, beliefs, feelings, assumptions, expectations, attitudes, norms, and values ". The elements of school culture are grouped into two categories, namely the visible element and the invisible element. Invisible elements can be manifested conceptually / verbally as well as visual material. Verbal invisible elements include: (1) vision, mission, goals and objectives; (2) curriculum; (3) communication language; (4) school narrative; (5) narrative figures; (6) organizational structure; (7) rituals; (8) ceremonies; (9) teaching and learning procedures; (10) regulation, reward system, and punishment; (11) social psychology services; (12) patterns of school interaction with parents. Visible elements of the visual / material include; (1) facilities and equipment; (2) artifacts and mementos; And (3) uniforms' clothing. The invisible elements include the philosophy or the basic view of the school on the broad reality, the meaning of life, the task of man in the world, and the values. All the invisible elements are something that is considered important and should be championed by the school. It is therefore stated conceptually in the form of a more concrete vision, mission, goals, and objectives to be achieved by the school (Sastrapratedja in Ahyar, 2009).

School management becomes one of the determinants of good / bad culture formed in schools. The lack of attention of the principal's management towards the development of school culture has an adverse effect on the character building of learners to the low productivity and effectiveness of the school. Posnick \& Goodwin in Abdi (2008) state "school culture has an impact on the accomplishment and behavior of students, as well as the motivation, productivity and job satisfaction of teachers. The cultural substance will provide support and identity to the school and will form a framework for learning activities. A positive school culture can create a culture of quality, such as a culture that always supports excellence, a culture of discipline, a culture of togetherness, and other cultures that are oriented towards the quality of education. This is also supported by the results of research conducted by Ali, etc (2016) which states "the highest level of school culture will help achieve the effectiveness of schools at the highest level".

The development of SMK culture is done with the aim that the development of values that are relevant to the needs of individual learners and industry. Changes in demands on the level of vocational graduate of SMK indicate the two challenges that need to be answered in the implementation of SMK education in the future. First, the implementation of vocational education should produce graduates in accordance with the needs of the labor market. Second, vocational education must be implemented by taking into account the characteristics of educated participants. Thus, SMK as one of the national education services will be able to provide services to two parties at once, namely service to the needs of national development indicated by the needs of the labor market and service needs of citizens of education indicated by attention to the characteristics of learners (Kemendikbud: 2016). Development of values in SMK must meet the needs of learners in: (1) developing a positive appreciation of work in building a work culture (Heinz: 2009); (2) building a learning culture, innovative, creative and productive culture (Thompson: 1973; Gill , Dar, \& Fluitman: 2000); (3) empowering learners to find employment and decent income (Gill, Dar, \& Fluitman, 2000); (4) develop a career in accordance with the competence of the selected expertise (Kellet, Humphrey, Sleeth, 2009); (5) facilitate the fulfillment of all students' 
physical and non-physical, moral, and future needs to live comfortably, safely and happily in society (Rojewski, 2009).

This study examines deeper on the development of culture in SMK Negeri 9 Padang which is the favorite SMK with A accreditation in each of its expertise programs as well as appointed to be one of ten SMK referrals in Indonesia. The results of this study is expected to be used as a reference for the head of vocational school in an effort to develop vocational culture in school.

\section{RESEARCH METHODOLOGY}

This research was done by employing qualitative approach. This research conducted a thorough study of the object under the study by using data collection techniques directly from people in their natural environment (in this case school environment). Data collection techniques in this research are observation, interview, and documentation study. Data and information gathering were done to find various efforts undertaken to develop the school culture in an effort to build the character and competence of the students. The informants chosen in this study are the related elements that are able to provide the necessary data and information related to the effort of developing the school culture. Selection of informants was done by using snowball technique (Snowball sampling). For the purposes of this research, the authors set informants of the following elements: principals, heads of study programs, teachers, learners, and school staff.

Data analysis in this research follow the stages of qualitative descriptive analysis technique. Data analysis activities used the steps proposed by Miles and Huberman (1992), namely (1) data collection, (2) data reduction, (3) data presentation, and (4) conclusion drawing. To ensure the validity of the data: (1) repeated observations of school activities conducted by both programmable and spontaneous schoolchildren and (2) triangulation to ensure that the data collected is consistent with the facts on the ground. Triangulation in this research was done by cross-method triangulation (using multiple data collection methods) and triangulation of data sources (selecting appropriate data sources).

\section{FINDING AND DISCUSSION}

Cultural development of SMK Negeri 9 Padang was done in three ways: (1) quality culture, (2) regulation, and (3) socialization value.

\subsection{Development of School Culture through Quality Culture}

Quality culture is a standard set in the management system of SMK Negeri 9 Padang continuously and comprehensively touches all work units. Suharto (2012), states that concrete steps quality assurance is done through the planning stage. This means that the initial action of the school is to establish a quality plan that will be implemented by mapping the quality condition, determining the objectives and quality targets to be achieved.

The first impression in the management of the quality culture of SMK Negeri 9 Padang is to establish policies and quality objectives as an indicator of success. The objectives and quality policy are realized through the implementation of quality management in each work unit of training: (a) student guidance services; (b) student learning resources service; (c) industrial work practices; (d) entrepreneurship; and (e) extracurricular. In its implementation, SMK Negeri 9 Padang consistently maintains the quality management system and the effectiveness of each work unit in accordance with international standard quality management system for customer satisfaction. The efforts undertaken are: (1) to implement quality management system in each work unit; (2) coordinate existing work units with reference to the process of quality management system; (3) provide the necessary resources and information in the application of the quality management system; (4) monitor, measure and analyze, and make continuous improvements to each process; (5) control the work process involving other parties to ensure the suitability of the quality of the training and the requirements of the international standard quality management system.

Moerdiyanto (2007) stated that school culture can be developed through two approaches: structural vocational education actually holds the principles of industrial work, where one form of development of a positive work culture is through quality management. Schools need to be encouraged not only to look at aspects of management input but far more important on the management process. The application of quality management in schools should consider the following: (1) quality is the work of everyone, (2) the quality of the prevention, not the result of an inspection or examination; (3) quality means fulfilling the wants, needs, and tastes of consumers, 4) quality demands close cooperation, (5) quality demands continuous improvement, and (6) quality must be based on strategic planning (Daryanto: 2015).

A research done by Arobi (2013) states that the culture of quality in SMK PGRI 1 Karanganyar improved learning outcomes of learners as the implementation of school-based management programs, school self-evaluation, and minimum 
service standards. In this case, quality management is closely related to the leadership of the principal and the involvement of various elements of the school in carrying out the work by meeting the established quality standards. Quin, etc (2015) shows that there is a significant relationship between leadership practice and school culture and school culture with the achievement of learners. The implications of this study are: principals use the transformational leadership practices has an impact on the achievement of learners through the establishment of an effective school culture.

Sarason in Moerdiyanto (2007) mention that school culture can be developed through two approaches, namely structural approach and cultural approach. Efforts to improve the quality of schools need to understand the culture / school culture as its basic capital. Each school has a unique pattern based on the interaction of components of the school community internally and externally. Therefore, by understanding the characteristics of school culture, it will be able to do real action in improving the quality of schools. Development of school quality with cultural approach is believed to drive long-term improvement effort. Kotter (1996) states that structural structures through a set of rules and formal commandos will only be able to restructure behavior in the short term. A more appropriate intervention to build a school's quality culture is through a cultural approach that, in the long run, will be able to drive change steadily. The development of cultural models is more about improving the mind-set, motivation and cultural behavior of all schoolchildren.

Culture development of SMK Negeri 9 Padang through quality culture can be visualized in chart 1 .

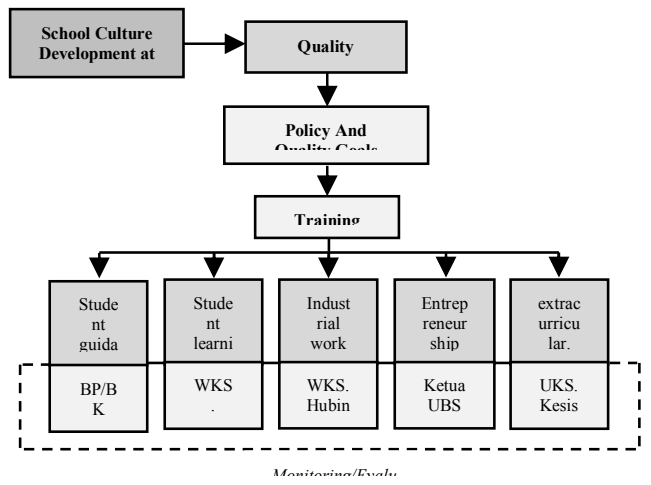

Figure 1. Development School Culture through quality culture

\subsection{Development of School Culture through Regulation}

Cultural development through regulation is done to regulate the behavior of learners at school. These regulatory forms comprise of policies, disciplines equipped with reward and punishment systems and
SOPs. Policy in SMK Negeri 9 Padang which is associated with the development of school culture is contained in the quality policy as described in the previous section. While the determination of SOPs is made to organize the work steps of learners at the time of practice and work in Unit Production (UP). Value socialization is part of the school culture development management step through: (a) installation of slogans that demonstrate schooldeveloped values, and (b) socialization of values to teachers and school employees to transfer to learners through Exemplary and value integration in learning. This is supported by the research result of Diayuningsih \& Suryanto (2014) expressing the development of character values through academic culture oriented on the quality of education conducted by: (1) conditioning, (2) routine activities, (3) advising or reprimanding, (4) reward and punishment.

The rules are contained in the document of the rules of discipline of the students who legally bind the students of SMK Negeri 9 Padang. Preparation of the rules refers to the school value system and involves several related elements, such as principals and representatives, disciplinary commissions, teacher assemblies, and committees. SMK Negeri 9 Padang recognizes that rewards are very important in improving the positive performance and productivity of students, teachers, and school employees. Award (reward) is given in the form of material and nonmaterial. Basically, the school more often uses nonmaterial award such as awarding certificates of awards to the learners or teachers who excel. Nomination of learners and teachers per semester and informal social awards such as praise, smile, shoulder tap, and ask for advice.

The enforcement of punishment is an integrated part in the effort to build ethical behavior and discipline of the students of SMK Negeri 9 Padang. Sanctions for violations of school rules and regulations are grouped into five categories:: (a) sanction specific rules of self-discipline, (b) sanction specific rules of attendance in learning, (c) sanction of special rules of learners in the improvement and enrichment, (d) sanction of special rules of learners who do not carry out flag, spiritually and go to ceremonies, and (e) sanctions on all local members responsible for activities in the form of equipment activity fines.

Culture development of SMK Negeri 9 Padang through regulation can be visualized in chart 2 .

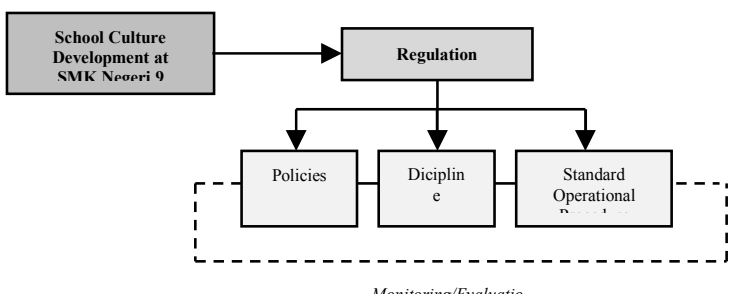


Figure 2. Development School Culture through regulation

\subsection{Development of School Culture Through Value Socialization}

Value socialization is a part of the school culture development management step through: (a) installation of slogans that demonstrate schooldeveloped values, and (b) socialization of values to teachers and school employees to transfer to the learners through exemplary and value integration in learning. The slogan is a phrase or sentence that briefly and clearly expresses the values that are believed to be communicated to the entire school community. Selection of phrases in the slogan describes the direction of the school view of the organizational structure of school activities at the same time can be a distinguishing characteristic of one school with another school. SMK Negeri 9 Padang is a tourism SMK that upholds the values of hospitality. This is the evident from many slogans on display in schools such as: Serve With Heart, Budayakan 5S (Senyun, Sapa, Salam, Sopan, Santun), Let's Create Behavior Healthy and Clear in Our Environment, Saving is Smile in The Hereafter, And We Are The Real Entrepreneur School.

Socialization of value through teachers and employees is an effort to improve teachers and employees' understanding of the basic values held by schools. Socialization of value is done with the aim that teachers and employees can internalize these values in themselves and further in the end can transfer it to the learners both in everyday behavior through exemplary and integrate in learning. The learning process is a form of curriculum implementation that allows teachers to embed the values of choice relevant to the subject. The process of value integration in SMK Negeri 9 occurs during classroom theory learning, practical activities, and work in production units. This effort is done in order to build the work character and entrepreneurial spirit of the learners.

The socialization of these values is an attempt to spread the values that are held to all school members. This socialization aims to make every citizen of the school able to adjust the values it carries with the values held by the school. Socialization can be conceptualized as a process consisting of three stages: pre-admission, encounter, and metamorphosis. (Robbins \& Timothy: 2008).

The pre-admission stage recognizes that each individual comes with a certain set of values, attitudes, and expectations. Related to this in schools generally always implement the orientation of new learners, it is necessary to do the correct mechanism to introduce new learners with attitudes and behaviors that desired school. At the stage of the encounter, learner faces the possibilities between expectations of learning, friends, teachers, and the condition of the school as a whole with reality. If the expectations and realities facing learners are different, they must run socialization to release assumptions that they previously held and replace them with other assumptions deemed appropriate by the school. At the stage of socialization the role of Guidance and Counseling Unit (BK) is very important in guiding learners to change the paradigm to understand and accept the values held by the school. Metamorphosis stage is a process to make learners have values held by school. Socialization of value at this stage is done during the learners run the process of education. Cultural development programs in each training unit play an important role in the process of internalizing values to learners. Successful metamorphosis process of socializing this value is when learners understand the school system as a whole, related to its responsibilities, rules, procedures, and practices received informally. Successful metamorphosis will have a positive impact on their productivity and commitment to schools and reduce their tendency to demonstrate behaviors that oppose school values and norms. Related to this, Peterson (2002) states "When a school has a positive, professional culture, one finds meaningful staff development, successful curricular reform, and the effective use of student performance data. In these cultures, staff and student learning thrive. In contrast, a school with a negative or toxic culture that does not value professional learning, resists change, or devalues staff development hinders success ".

Cultural development of SMK Negeri 9 Padang through value socialization can be visualized in chart 3.

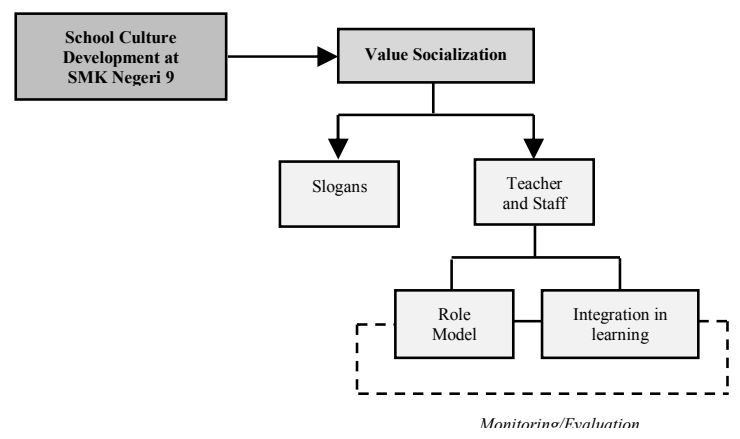

Chart 3. Development School Culture through vaue socialization

Development of school culture through regulation and value socialization is done to support the achievement of quality culture through the implementation of the training. In other words, the values that are socialized with the binding regulations are substituted through the implementation of the training of learners during their education in school. To ensure the process of cultural development is done well monitored by disciplinary commissions, 
student representatives, and teachers picket. Furthermore, the evaluation of these three aspects is done by the principal at regular intervals.

\section{CONCLUSION}

Development of school culture requires a clear and comprehensive mechanism. The development of a school culture should start from the principal's commitment to create an effective atmosphere for the development of values to be developed. Based on the results of this study, cultural development can be done through three ways: (1) Development of school culture through a culture of quality. Quality culture is a standard defined in the school management system that continuously and comprehensively touches all work units by establishing policies and quality objectives as an indicator of success. (2) Development of school culture through regulation. Establishment of regulation aims to regulate the behavior of learners while in school. These regulatory forms comprise of policies, disciplinary systems equipped with reward and punishment systems and Standard Operating Procedures (SOPs). (3) Development of school culture through value socialization. Value socialization is part of the school culture development step through: (a) the installation of slogans that demonstrate the values developed by schools, and (b) the socialization of values to teachers and school employees to transfer to learners through exemplary and value integration in learning.

\section{REFERENCES}

[1] Abdi, Rahmani. 2008. AL- Risalah Jurnal Ilmiah Keagamaan dan Kemasyarakatan. http://web.stairakhaamuntai.ac.alrisalah_vol.4_no.1_th.pdf. Diakses tanggal 16 Januari 2017

[2] Ahyar. 2009. Jurnal ilmiah "kreatif" Sekolah Sehat Sebuah Tinjauan Akademis". http://jurnal.pdii.lipi.go.id/admin/jurnal/6109172 6.pdf. diakses tanggal 10 Januari 2017.

[3] Ali, dkk. 2016. School Culture and School Effectiveness: Secondary Schools in Pakistan (Malaysian Online Journal of Education Management). Vol 4, Issue 4. Halaman 50-65.

[4] Callan,VJ. 2003. Generic Skills Understanding Vocational Education and Training Teacher and Student Attitudes. Adelaide: NCVER.Clarke, M. 2007. Understanding and Managing Employability in Changing Career Contexts. Journal of European Industrial Training. Vol 32 No. 4, pp 258-284.

[5] Daryanto. 2015. Pengelolaan Budaya dan Iklim Sekolah. Yogyakarta: Gava Media.

[6] Diayuningsih, Irma \& Totok Suyanto. 2014. Pola Pengembangan Nilai-Nilai Karakter Melalui Kultur Sekolah di SMK Wachid Hasyim
2 Taman Sidoarjo. Jurnal Kajian Moral dan Kewarganegaraan. Nomor 2, Vol 1. Hal 31-45.

[7] Gill,I.S.,Fluitman.F.,\& Dar.A. 2000. Vocational Education and Training Reform, Matching Skills toMarkets and Budgets.Washington: Oxford University Press.

[8] Heinz .W.R 2009. Redefining the Status of Occupations; in Rupert Maclean, David Wilson, ChrisChinien; International Handbook of Education for the Changing World of Work,Bridging Academic and Vocational Learning: Germany: Springer Science+Business Media.

[9] Instruksi Presiden Nomor 19 tahun 2016 tentang Revitaslisasi Pendidikan Vokasi.

[10] Kotter, John P 1996. Leading Change. Boston: Harvard Business School Press.

[11]Luneburg, Fred C \& Allan C. Ornstain. 2000. Educational Administration: Concept and practice. USA: Thomson Learning.

[12]Miles, Mattthew B. and A. Michael Huberman.1992. Qualitative data Analysis. Sage Publication, Inc.

[13] Moerdiyanto. 2007.Potret Kultur Sekolah Menengah Atas, Tantangan dan Peluang.Artikel Cakrawala Pendidikan

[14] O’Brien, PS. 1997. Making College Count: A real World Look at How to succeed in and After College. USA: Graphic Management Corp.

[15]Permendiknas Nomer 19 Tahun 2007 tentang Standar Pengelolaan Pendidikan oleh Satuan Pendidikan Dasar dan Menengah.

[16]Peterson. 2002. Reculturing Schools. http:// smhp. psych. ucla. edureculturingschools. pdf. Diakses tanggal 14 Januari 2017.

[17]Quin, dkk. 2015. The Correlation Between Leadership, Culture, and Student Achievement (Journal of New Horizons in Education). Vol 5, Issue 2.

[18] Robbins, Stephen P \& Timothy A. Judge. 2008. Perilaku Organisasi (Buku 2): Edisi 12. Jakarta: Salemba Empat.

[19] Rojewski. J.W 2009. A Conceptual Framework for Technical and Vocational Education andTraining; in Rupert Maclean, David Wilson, Chris Chinien; International Handbook of Education for the Changing World of Work, Bridging Academic and Vocational Learning: Germany: Springer Science+Business Media.

[20] Thompson, John F, 1973. Foundation of Vocational Education Social and Philosophical Concepts.Prentice-Hall: New Jersey.

[21] Undang-Undang Nomor 20 Tahun 2003 tentang Sistem Pendidikan Nasional. 